$\begin{array}{ll} & \text { Etnográfica } \\ \text { etnográfica } & \text { Revista do Centro em Rede de Investigação em }\end{array}$

Antropologia

vol. $19(2) \mid 2015$

Vol. $19(2)$

\title{
Breadwinners, sex machines and romantic lovers: entangling masculinities, moralities, and pragmatic concerns in touristic Cuba
}

Provedores de sustento, máquinas sexuais e amantes românticos:

masculinidades, moralidades e preocupações pragmáticas interligadas na Cuba turística

\section{Valerio Simoni}

\section{(2) OpenEdition}

Journals

\section{Electronic version}

URL: https://journals.openedition.org/etnografica/4039

DOI: 10.4000/etnografica.4039

ISSN: 2182-2891

\section{Publisher}

Centro em Rede de Investigação em Antropologia

\section{Printed version}

Date of publication: 1 June 2015

Number of pages: $389-411$

ISSN: 0873-6561

\section{Electronic reference}

Valerio Simoni, "Breadwinners, sex machines and romantic lovers: entangling masculinities, moralities, and pragmatic concerns in touristic Cuba", Etnográfica [Online], vol. 19 (2) | 2015, Online since 22 June 2015, connection on 09 February 2022. URL: http://journals.openedition.org/etnografica/4039 ; DOI: https://doi.org/10.4000/etnografica.4039

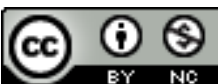

Etnográfica is licensed under a Creative Commons Attribution-NonCommercial 4.0 International License. 


\section{Breadwinners, sex machines and romantic lovers: entangling masculinities, moralities, and pragmatic concerns in touristic Cuba}

\section{Valerio Simoni}

Experiences of sexual and love relationships with tourist women lead Cuban men to articulate and act upon different - often contradictory - models of masculinity. Gossiping among peers, it is common to brag about one's sexual conquests and exploits with tourist women; in contrast, when interacting with foreigners, men tend to insist on their allegiance to a romantic lover ideal. Intimate experiences with tourist partners also lead to reassess relationships with Cuban women, in which the men's wealth is portrayed as the key for accessing (just) sex. These contradictory enactments of masculinity call for a situated and multilayered understanding of Cuban men's affective, moral, and pragmatic concerns as they move in and out of the world of tourism. Important dimensions of their paradoxical enactments of masculinities can thus be highlighted and explained. What emerges is that in struggling to respond to competing demands, aspirations, and vectors of power, Cuban men's purposeful alignments as "breadwinners," "sex machines," and "romantic lovers" afford different relational possibilities and expressions of masculinity. By taking seriously these possibilities, the article illuminates the transformations of masculinities that tourism engenders, assessing its potential to amplify and subvert (stereo)-typical configurations of "being a man" in present-day Cuba.

KEYWORDS: masculinities, tourism, moralities, sex, love, Cuba.

Provedores de sustento, máquinas sexuais e amantes românticos: masculinidades, moralidades e preocupações pragmáticas interligadas na Cuba turística - A experiência de relações sexuais e amorosas com turistas do sexo feminino leva os homens cubanos a articular diferentes modelos de masculinidade, frequentemente contraditórios entre si. Entre pares, esses homens gabam-se das suas conquistas sexuais entre as turistas, mas na interação com as estrangeiras insistem na lealdade ao ideal de amante romântico. A intimidade com turistas conduz também à reapreciação das relações com as mulheres cubanas, nas quais a riqueza do homem é vista como a chave de acesso ao sexo (apenas). Estas performances contraditórias da masculinidade convidam a uma compreensão situada e multidimensional das preocupações afetivas, morais e pragmáticas dos homens cubanos na sua relação com o mundo do turismo, o que permite esclarecer e explicar dimensões importantes dessas atuações paradoxais. Para dar resposta a exigências, aspirações e vetores de poder conflituais entre si, o alinhamento intencional dos homens cubanos com as categorias de "provedores de sustento", "máquinas sexuais" e "amantes românticos” abre diferentes possibilidades de relacionamento e expressões da masculinidade. Encarando com seriedade tais possibilidades, o artigo contribui para a 


\begin{abstract}
compreensão das transformações da masculinidade geradas pelo turismo, avaliando o seu potencial para ampliar e subverter configurações (estereo)típicas do que é hoje "ser um homem" em Cuba.
\end{abstract}

PALAVRAS-CHAVE: masculinidades, turismo, moralidades, sexo, amor, Cuba.

SIMONI Valerio (valerio.simoni@graduateinstitute.ch) - Department of Anthropology and Sociology of Development, Graduate Institute of International and Development Studies, Switzerland.

IN THIS ARTICLE, I WISH TO SHOW HOW EXPERIENCES OF SEXUAL AND love relationships with tourist women led Cuban men to articulate and act upon different - often contradictory - models of masculinity. ${ }^{1}$ To understand such situated enactments of masculinity, I argue that one must pay attention to the moral and pragmatic concerns to which they responded, and in which they were entangled. Cuban men's purposeful alignments as "breadwinners," "sex machines," and "romantic lovers" afforded different relational possibilities and expressions of masculinity as people moved in and out of the tourism realm. It is by taking seriously these relational possibilities and the demands they generated that transformations of masculinity can be productively illuminated, and that tourism's potential to amplify and subvert (stereo)-typical configurations of "being a man" in present-day Cuba can be assessed.

Tourism in Cuba developed in earnest after the collapse of the Soviet Union. In 1990 president Fidel Castro declared the beginning of a Special Period in Time of Peace, a period of austerity, reforms, and economic restructuring which has been credited for the island's progressive but unsteady integration to a "larger global, neoliberal framework" (Cabezas 2009: 22). The key implications of the Special Period in its relation with the development of international tourism have been recently assessed by Cabezas (2009), who emphasizes how the crisis and the way the Cuban government coped with it resulted in the amplification of gender and racial inequalities and the emergence of new sexual formations that found expression in the tourism realm. Following the massive arrival of people from abroad, a wide range of tourism-related activities

I I would like to thank the Portuguese Foundation for Science and Technology (FCT) for supporting my research and writing with their Post-Doctoral Grant program (SFRH/BPD/66483/2009). The last stages of the publication process benefited from the support of the Swiss National Science Foundation (Ambizione Fellowship, PZ00PI_147946). Many thanks also to an anonymous reviewer for the useful suggestions and critiques on an earlier version of the article. Last but not least, this article would not have been possible without the collaboration of the Cuban men I worked with in Cuba, and my deepest gratitude goes to them. 
escaping state regulation flourished on the island, a place where interactions with foreigners had the potential of being more beneficial and gratifying than many other professional activities. Indeed, in spite of governmental efforts to control tourism, Cuban men and women found ways to avoid governmental restrictions and create opportunities to engage with tourists, offering their services as guides or companions, seeking foreign friendships, selling cigars, providing private taxis, accommodation or food, and - central to my concerns here - engaging in sex and romance with foreigners. This was the world of jineterismo - from the Spanish jinete (rider) - a contested term evoking the "riding" of tourists for instrumental purposes and often equated with notions of tourism hustling and prostitution.

Several authors have outlined the porosity (Argyriadis 2005: 47), the ambiguities (Berg 2004; Cabezas 2004; Fernandez 1999; Palmié 2004), and the kaleidoscopic character (Kummels 2005: 24) of jineterismo and other related phenomena and categories in Cuba - sex work, prostitution, and partnership for instance. Scholars have emphasized how jineterismo is a complex phenomenon, one which brings issues of morality, nation, race, class and gender into play (Berg 2004; Cabezas 2004; Fernandez 1999; Simoni 2008). One of the most tenacious and controversial lines of distinction in narratives of jineterismo related to gender, with the activities of women often acquiring a different connotation than those of men. Several authors have remarked that jineteros are less stigmatized in Cuban society than jineteras (Allen 2007; Alcázar Campos 2009; Berg 2004; Cabezas 2004; Palmié 2004). Whereas their activities are considered to pertain to a much more variegated and heterogeneous spectrum, which can include sex and romance with foreigners but is more broadly related to tourist-hustling (selling cigars, act as brokers, tourist guides, etc.), the activities of jineteras are more readily equated with prostitution and commercialized sex.

A consideration of gender and of the sexual dimensions of informal tourism-oriented activities in Cuba's Special Period also point to the emergence of other sexual identifications that complicate any heterosexist reading (Allen 2007; Couceiro Rodríguez 2006; Fosado 2005; Hodge 2001; Sierra Madero 2006; Stout 2007). Among them is that of the pinguero (from a slang term for penis, pinga), a neologism designating men whose activity had to do with their pinga. According to Cabezas, "while some pingueros identify themselves as straight, they tend to provide sexual services mainly to gay tourists because male-to-male practices are more lucrative than straight sex" (2004: 994). By contrast, the men considered in this article emphasized their distance from the world of pingueros, displaying rather homophobic attitudes and stressing their exclusively heterosexual orientation. They mostly saw themselves as being in a "line of women" (linea de mujeres), viewing their own activities as specifically tailored to the development of sexual/romantic relationships with female tourists, often with the stated goal of marrying one and being able to 
travel abroad. As the article shows, monetary transactions between these foreign women and Cuban men were fraught with controversy as they interfered with ideals of masculinity that saw men as women's providers. These findings may provide important clues for contemporary debates on "sex tourism" and the commoditization of sexuality in tourism settings, a line of analysis that will, however, remain largely out of the scope of this article, but which is nevertheless worth mentioning briefly here.

In the academic literature, much debate has been going on to ascertain whether women traveling to poorer countries, notably in the Caribbean, engage in "sex tourism" "as men do" (itself a problematic assumption, see Simoni 2014), or if the term "romance tourism" (Pruitt and LaFont 1995) or "companionship tourism" (Herold, Garcia and DeMoya 2001) would be more appropriate to describe these relationships. According to Jeffreys, the matter often revolves around whether researchers "privilege the oppressions of class and race over that of gender in their analyses" (2003: 234), or vice versa. In a more nuanced way, Frohlick has recently argued that "[w]ithin the global economy, women from First World countries can and do exert their relative economic power over local lovers and others in the communities to which they travel in Third World countries, but power associated with masculinity complicates this schema" (2007: 141). Regarding the behavior of tourist women which I will not be able to address in this article - my conversations indicated that none of them was straightforwardly paying for sex with Cuban men. ${ }^{2}$ My findings converge here with the researches of Pruitt and LaFont (1995) and Frohlick (2007), which suggest that tourist women engaging with local men in the Caribbean may be looking for more than "just sex" - namely romance and intimacy. In line with these authors, my examination of the men's perspective in this article also shows that Cubans did not simply adapt to the foreigner's tastes and desires, but that different vectors of power could inform their relationships, among which gender played an important role. Taking into account the local men's negotiations of masculinity enriches our understanding of intimate encounters and their power dimensions in these tourism settings, shedding light on relational dynamics that may otherwise be neglected, particularly when relying on reductive readings in terms of sex tourism and prostitution.

The Cuban men that appear in the following pages were all of very humble origins, and had often migrated to tourism centers from less privileged areas of the country. I met them mainly through my frequentation of tourist sites in the city of Havana, the rural town of Viñales (200 kilometers west of the capital),

2 Elsewhere (Simoni 2014), I have shown that monetary exchanges could become problematic also in relationships between tourist men and Cuban women, and that even in this case the "sex tourism" designation could silence a range of differences and nuances that were very important to my research participants. 
and the beach resort of Playas del Este (half an hour drive east of Havana) the places where I carried out 13 months of ethnographic fieldwork between 2005 and 2014. With some of them, I developed very strong ties, and was thus able to follow their engagements in and out of tourism settings, observing and participating in the different realms of interaction that characterized their everyday lives. It is this multiplicity of perspectives and ways of being that interests me here (see also Simoni 2013). More than pointing out differences between Cuban people, my analysis aims to account for heterogeneity within the lives of the subjects of my investigation - the multiple and paradoxical positionings and subjectivities they inhabited as they worked over different models of masculinity. Accordingly, what is important to consider is the situational dimension of such enactments of masculinity. As Vale de Almeida put it, "masculinities are situationally negotiated" (1997: 147), and such negotiations may be fruitfully highlighted once we acknowledge "that the answer to what constitutes proper manhood shifts not only with time, but also according to immediate variations in social situations and contexts in the lives of specific men" (Oxlund 2012: 32). It is this situational dimension that I want to retain in considering how my research participants enacted the "sex machine," the "breadwinner," and the "romantic lover" categories. Let me start with the first of these axes of masculinity, the one emphasizing sexual potency.

\section{"SEX MACHINE"}

As a fruitful entry point into this vector of masculinity and the alignments it generated, let me start from a brief extract from a conversation I had with Umberto, an Afro-Cuban Rasta in his thirties with whom I spent several evenings discussing about relationships with tourist women. ${ }^{3}$ Like many other men in his circle, Umberto talked with pride of his sexual feats, his numerous girlfriends, and his skills in seducing foreign women: "It's been years now that I am in this. I know how to work the woman [trabajar la mujer], I don't fail [yo no fallo, i.e. in the seduction enterprise]!" ${ }^{4}$ And indeed, while not infallible,

3 All personal names of research participants appearing in the article are fictional. Those I got to know as "Rasta" in tourism milieus in Havana were mainly Afro-Cuban men adopting a subculture style that may be summarily characterized as valorising blackness and Afro-related cultural expressions, sporting dreadlocks and Rastafari-inspired accessories and clothing, and privileging a laid-back approach to tourists. These people generally self-identified, and were seen by others, as Rasta. See the research of Hansing (2006) for more on the Rastafari movement in socialist Cuba and what this author categorizes as "Rasta jineteros." For more scholarly considerations on the success, and the controversial adoption of a Rasta style by local men willing to seduce foreign women in tourism destinations - from Jamaica's "rent-a-dread" to Indonesia's "Kuta cowboys" - see in particular the works of Pruitt and LaFont (1995) and Dahles (1997).

4 All the quotes from research participants that appear in the article have been translated into English by the author, and are based on recollections after the events took place. 
Umberto was quite successful in establishing intimate relationships with female tourists, and would not hesitate to boast about his latest adventures when talking with his friends and peers.

The moments in which sexual conquests of foreign women were much talked about and exalted were moments of male sociability, which saw my informants engage in boastful exchanges to assert their virile reputation and establish masculinity-grounded standings. Such situations resonate with notions of "homosociality" or "homosociability" (Almeida 1997) describing the (often leisure-oriented) spaces of men to men interaction, helping consolidate male bonding and heterosexual identities, and whose importance in constructions of masculinity has been highlighted by scholars (Gutmann 1997), notably in the context of Latin America (Vigoya 2001), and also in Cuba (Lundgren 2011; Morel 2012). My research participants' inclination to talk among themselves about their sexual feats may be read as expressing a value system based on "reputation," as theorized by Wilson (1969) for the Caribbean context, described "as a lower-class and masculine sphere of public performance, enacted in such venues as street corners, the political platform, the rum shop, and the market, and on the musical stage" and "demonstrated through sexual prowess, verbal wit, and economic guile" (Freeman 2007: 5).

It was precisely in moments of homosociability that the importance of sexual behavior in the enactment of masculinity became paramount. Sexual feats became something to be proud of, to boast about, and could come to exemplify one's excellence at being a man. ${ }^{5}$ While this is not unique to Cuba, the view that men have by their very own nature "inherent uncontrollable sexual drives" (Lundgren 2011: 55; Alcázar Campos 2009) seems very widespread in this Caribbean country. According to Alcázar Campos (2009), this is also what helps explain why any provision of sexual services to foreign women could be framed and normalized within an hegemonic view of masculinity that valued sexual exploits and promiscuity as marks of virility.

The men's tales of sexual feats with foreign women actualized an hyper-sexualization whose roots may be traced back to the colonial past of the island, to which such enactments of masculinity seem inexorably entangled. Several scholars writing about the recent developments of tourism in Cuba underline continuities between the sexualized images of "hot" Cuban people and the slavery and colonial past of the island (Fusco 1997; Kneese 2005; Kummels

5 Discussing Herzfeld's work on manhood among Glendiot Cretan villagers, Zigon (2008) considers that what is important and counts as masculinity in this case is not simply to act as men are supposed to do, according to the norm, but to act "in such a way that it is recognized as beyond the norm," to show excellence and virtuosity in one's enactment of being a man. This would explain why among the Glendiot "there is less focus on 'being a good man' than on 'being good at being a man'”- "a virtue theory of masculinity" (Herzfeld 1985: 16, quoted in Zigon 2008: 94) that resonates quite well with the Cuban material discussed here. 
2005; Sanchez Taylor 2000). While these considerations have mainly regarded the eroticization of the "mulatta" (la mulata) and black women, "white stereotypes of primitive black male potency" (De Albuquerque 1998: 50), and colonial, sexualized racist fantasies of "the "big black dick" (Sanchez Taylor 2000: 49) are also said to lure female (sex) tourists to Caribbean countries like Jamaica, Barbados, Cuba, and the Dominican Republic (De Albuquerque 1998; Kempadoo 2004; Sanchez Taylor 2000). In her research on the negotiation of intimacy between tourist women and local men in Caribbean Costa Rica, Frohlick (2007: 150) shows how "racial stereotypes and ethnosexual dynamics of mutual desire (that is, the desire for black men by white foreign women and desire for white foreign women by black men) play out such that the men imagine themselves as hypersexual black men because in part this is how they are imagined by the tourists." For Frohlick, “[m]en's sexual subjectivities, complicated by their hybrid identities as Afro-Caribbean-Costa Rican, are forged through encounters with foreign women" (2007: 150), something that leads her to consider that "[m]asculinity is learned, negotiated, and performed within this specific context and political economy of mutual interracial erotic heterosexual desire" (2007: 151).

What my research suggests (Simoni 2011,2013 ) is that besides continuities in the racialization of sexuality - most notably in the (hyper)sexualization of Afro-Cubans (see Allen 2007; Fernandez 1999, 2010) - the stereotype of the caliente ("hot") Cuban could also be re-actualized in a more culturalist/nationalist vein in specific tourism contexts, and applied to Cubans with little regard to their racial attribution. In her study of interracial couples in contemporary Cuba, Fernandez (2010: 126) notes that while "racist ideology supported ample stereotypes of black males' primitive, animalistic, and uncontrollable sexuality $[\ldots]$ notions of potent sexuality were not exclusively associated with black and mulatto Cubans." Accordingly, "perceptions of Cubanness, in general, were closely linked with sexuality, and there was a sort of national pride about Cuban's mythical sexuality and ardency" whereby "Cuban men and women were seen to possess an uncontrollable 'latino passion,' particularly in comparison to Europeans and North Americans" (Forrest 1999, quoted in Fernandez 2010: 126). It was precisely such comparison and relational opposition that acquired salience in the tourism contexts where I worked, and that helps explain the overarching characterization of Cuban people as "hot," or at least "hotter" than the foreigners visiting the tropical island. " "No one fucks like Cubans!" maintained my friend Manuel, a white Cuban in his late twenties, when comparing the sexual abilities of Cuban people to those of foreigners.

6 An interesting parallel may be drawn here with Piscitelli's work on sex travel in Fortaleza (in Brazil's Northeastern coast), and her reflections on "the production of the idea of a 'Brazilian sexual culture"” (2014: 280). 
It was not the physical size of the penis that mattered here - as the "big black dick" myth (Sanchez Taylor 2000: 49) would have it - but Cubans' sexual prowess, which was deemed exceptional, unique, and cast as a national trait. What is worth noting in this case is also how masculinity became entangled in wider difference-producing processes (Strathern 1988, as discussed in Cornwall and Lindisfarne 1994: 40-41), in this case the us-Cubans/them-foreigners divide.

Beyond one's exploits in sexual intercourse, what mattered was also the ability to seduce foreign women. In conversations about their adventures with tourists, my Cuban research participants liked to emphasize their seduction skills and talent. "He is confused" (El está mareado), "he is not going to do anything [with the girl]" (no va a hacer nada), "he doesn't know!" (no sabe) was Umberto's critique as he closely scrutinized one of his colleagues' clumsy attempts to seduce a young Norwegian girl that he himself coveted. This he contrasted with his subtler moves and flirting abilities. In the course of several lengthy conversations we had about his and his peers' ways of relating with tourists, Juan - a young Afro-Cuban man in his twenties that frequented the Rasta clique in Havana - told me about the importance of one's ability to "vibrate" (vibrar), to "have a good vibration," one that would lead tourists to stick to you as to a magnet. This meant "knowing how to talk" (saber hablar), how to capture her attention, how to care for details, sensing her weak spots, and "killing her" (matarla) with one's wit and seductive power. ${ }^{7}$

In the course of fieldwork, I was often confronted with heated debates which saw Cuban men arguing about one's knowledge of foreign women, and how best to deal with and seduce them. In his late twenties, Rodrigo was a white Cuban man who had been engaging with foreign women for about eight years. He was widely recognized by his peers, often with palpable envy, as someone who never failed to get the women he liked, and he didn't hesitate to boost about such "infallibility." In the course of the evenings I spent with him and his friends in tourist bars and clubs, the conversation often revolved around the best tactics one should employ for flirting. This led to constant bickering, controversy as well as more practical exemplifications of one's skills via concrete attempts to seduce one of the tourists that were present. Much like for the Cuban practice of piropos - a term translated as "compliment" or "flattery" that "generally refers to verbal comments by men to women in street interaction," according to Lundgren (2011: 97) - we are here in situations where men's public performances were not just directed at the woman at

7 Drawing on their Jamaican case, Pruitt and LaFont (1995: 427) refer more generally to Caribbean men's valuing of "proficiency at 'sweet talk' (Abrahams 1983, Wilson 1973)," and argue that "ardent declarations of love, praises of beauty, and the like [...] are a common part of a Jamaican man's repertoire." 
stake - whose reaction to the advances could even fall into second plan - but at the other men who were present, and who were assessing one's seduction skills. Following Lundgren, we can argue that these were situations in which "the woman became a necessary instrument through which the man could gain a position as brave and daring in relation to this homosocial environment" (2011: 106). As argued also by González Pagés "the construction of hegemonic masculinity in Cuba" does indeed include "ingredients such as the demand to constantly demonstrate virility and bravery in front of other men" (quoted in Lundgren 201 1: 102).

In his advances to tourist women, Rodrigo exemplified braveness in front of his peers. His witty, playful, and daring attitude seemed to bring him much success in relationships with foreigners. Proud of his seductive power, Rodrigo told me that whenever he went out in tourist venues at night, he was almost certain to end up with some foreign girl, in a way that was almost beyond his control (note once again the "uncontrollable sexuality" trope). That was why, while he waited for his more "official" girlfriend and soon-to-be wife to visit him from Austria, he preferred to spend most of his nights at home, calm (tranquilo), so as to avoid the spread of potentially harmful, envy motivated gossiping that could reach the ears of his Austrian partner, with disastrous consequences for Rodrigo's marriage plans. As was rather common among Cuban men who entertained several simultaneous affairs with foreign women, Rodrigo was afraid that the gossip (chisme) of envious people could impact negatively on his ongoing relationships. This had happened to his friend Emilio (see below), who saw the "love of his life" with a Swedish woman destroyed by malicious rumors on his simultaneous affair (trivial in Emilio's eyes) with a German lady, rumors that had intentionally reached the Swedish woman in question. While at home, however, Rodrigo's exuberant sex life was not to be put on hold, as he enjoyed the company of a teenage Cuban girlfriend that could satiate his professed sexual appetite.

While speaking to me rather openly about the fact that in the last eight years he had lived off his foreign girlfriends' financial help, Rodrigo's narratives emphasized the fact that it was him who had chosen the women in question, and that it was him who set the terms of their engagement. Illustrative in this sense was the story of a Dutch girlfriend who, wanting to make him a surprise, had sent Rodrigo a parcel containing everything he would have required to visit her in Holland - including visa and plane ticket. In the milieu of jineterismo in which Rodrigo evolved, this was arguably one of the most valued prizes one could hope for. As he proudly put it, however, and contrary to everyone's expectations, Rodrigo had refused his girlfriend offer, and even chastised her for taking the initiative without discussing the plan with him beforehand: "I like things to be talked through. Who told you [the Dutch woman] that I wanted to come [to Holland] now? Perhaps I wanted us to get 
to know each other a bit more, don't you think? I don't like things to be done this way, I don't like to be manipulated! [no me gusta que me manipulen]" This was his reprimand. Rodrigo told me that "everyone else" - i.e. his peers - had judged him crazy to refuse such offer. On the other hand, by distinguishing himself this way, he had set himself out as a man who had his own life in his hands, who didn't let women make patronizing assumptions about his needs and desires and make decisions for him. Following the same logic, and contributing to similar enactments of masculinity, was my informants' emphasis on the fact that it was them, as men, who had seduced their foreign partners and won them over with their manly skills and abilities. A particular configuration of agency and power relations was thus actualized, which put the men clearly above their female partners in terms of decision making, an important issue to which I shall return below.

Rodrigo's narrative directs our attention to the different vectors of power (Simoni 2008) that took shape in these gendered relationships between Cuban men and foreign women, most notably the contentious power dynamics associated with striking economic asymmetries (see also Frohlick 2007, and Pruitt and LaFont 1995). Indeed, tensions could quickly arise once this other axis of Cuban-foreigner differentiation was brought to the fore: that of economic resources, which carried its own effects and implications as to what being good at being a man amounted to, not on sexual grounds this time, but in terms of economic agency.

\section{"BREADWINNER"}

Grounded in the reification of a radical asymmetry of resources, jineterismo could embody for my Cuban informants a just struggle, a redistributive tactic in an unequal world in which wealthy tourists visited a developing country like Cuba. In line with what many believed the government was itself doing - "squeezing" foreign visitors to bring in as much hard currency as possible jineterismo became a rightful way for them to get their slice of the tourism cake, part of a nation's cunning tactics to siphon capitalist wealth. If some deception at the tourists' expenses was involved, it could be easily justified via the adoption of an us-Cubans versus them-tourists approach. In this frame of legibility, national belonging and political-economic considerations seemed to take precedence over gendered lines of differentiation. In other words, a Cuban man could reasonably justify profiting from a foreign women once the Cuban-foreign divide was given precedence over the man-woman one. According to this scenario, Cubans were luring tourists into sexual/romantic relationships with the aim of gaining economic resources or migrating aboard via marriages and tourist-sponsored invitations. These were the sort of narratives that my Cuban informants could activate when talking among peers about their relationships 
with foreign tourists. In these contexts of interaction, their tendency was to objectify tourists, referring for instance to them as piezas ("pieces"), and to avoid delving on the emotions one felt for a foreign partner - something that could make you look foolishly vulnerable and naïve. Instead, people could align to the semantic registers and moral discourse of jineterismo, becoming "tourist-riders" who had conquered their foreign "victims" for essentially instrumental purposes, to provide for their socio-economic needs and desires and those of their family.

This was the kind of narrative that Rodrigo was likely to mobilize when explaining to his Cuban girlfriend Raquel what his relationships with foreign women were all about. Raquel was aware of his on-going affairs, and went along Rodrigo's scheming to obtain financial help from the foreigners. That was among the reasons Rodrigo liked her, because she "tolerated," because she had lived la calle (the street) and knew how to adapt to this rather unusual scenario. Coming from a very humble family - much like Rodrigo himself Raquel seemed happy to be living with him. She liked him and felt comfortable in his house, where she was also benefiting from his tourist-sponsored wealth and had a steady supply of gifts, good food and drinks, enjoying the exceptional use of a PC, an extensive DVD collection, and a range of other household appliances she had no prior access to. As other stories I gathered during fieldwork seemed to indicate, what was earned by Cuban men through informal engagements with tourists could become an appealing resource to seduce and nourish relationships with Cuban women, thus enabling the enactment of a breadwinner ideal of masculinity. It was precisely while reflecting on this state of affairs that my friend Ernesto - a young Afro-Cuban Rasta in his mid-twenties - told me, for instance, that once they realized that he was dealing with tourists, Cuban girls felt more attracted to him, as they expected he would have a steady influx of hard currency.

In regards to his relation with Raquel, Rodrigo was fulfilling an ideal of masculinity that seems to hold currency in Cuba. According to Gonzales Pagés (2004: 6), the archetype of the good provider of the household still informs gender relations in this Caribbean island. For a man to perform well as man, he is expected to be able to obtain material goods and achieve economically. Thus the anxiety experienced by Cuban men living through the current economic crisis, struggling to get cash (Gonzales Pagés 2004: 6), to successfully prove themselves in relation to such ideal. Research on masculinity in other parts of the world where men are similarly affected by economic crises or disadvantaged economic conditions, and where the breadwinner ideal remains strong - like the one of Aboim in Mozambique - suggests that "the lack of money or other material goods is compensated [...] by complex practices and discourses on sex and sexuality" (Aboim 2012: 82). This leads Aboim to argue that "sex comes into view as a capital that stands in distinct opposition to money, the 
last resort for those who lack other capitals" (2012: 80). While this may find some resonance with the Cuban case, my material suggests that the economic resources that people like Rodrigo drew from their tourist partners could also help them act as breadwinners in their relationships with Cuban women, preserving to some extent this moral configuration of their way of being a man.

At the same time, after living through eight years of relationships with foreign women who didn't expect him to provide for them, Rodrigo had also grown more and more detached, in his everyday practices, from such breadwinner ideal, and felt a certain anxiety in having to respond all of a sudden to its' moral demands in relation to Raquel:

"You know, it's about eight years that I have been living from the money of foreign women, it's about eight years I have not been working, and with her [Raquel] the other night, well, we watched a movie, we had sex, and then when I am half asleep, almost in the middle of the night, she tells me: 'Hey, listen, be aware that for tomorrow there is no rice [i.e. there's no food].' Fuck! It brought me this overwhelming feeling [expressing anxiety, as if having breathing problems], I had to go out of the house and take a walk [to recover]. It was about eight years that no one had told me that. Fuck, this gives you such a responsibility, you can't imagine."

In spite of the pressure he had felt, Rodrigo claimed that he wouldn't mind to provide for Raquel for the rest of her life, if she wished so. He would even "give her" a child, if that's what she wanted, and take financial care of the two, while at the same time being married and living abroad with one of his foreign girlfriends. As far as his aspirations for a "proper" marriage and family life were concerned, Rodrigo remained determined to fulfill them with a foreign woman, a woman he could love and feel comfortable with: "It's been eight years now that I have had this objective, and I am going to succeed," he maintained. Thus preserved were two different systems of value and models of masculinity, which we could illuminate through the notions of reputation and respectability (Freeman 2007: 5) and their on-going effects "as a living dialectic of dynamic sentiments, cultural forces of production that are constitutive of social actors themselves" (2007: 6). I have already referred above to Wilson's (1969) take on reputation. In regards to the other, "middle class ideological framework" of "respectability," Freeman notes that it encodes, by way of contrast, "ideals of domesticity, propriety, enacted through formal marriage" (2007: 5). Much like in the Barbadian case examined by Freeman, the example of Rodrigo considered here can similarly illustrate how "the two cultural dynamics" could be simultaneously embraced by the same person.

The pressure and anxiety experienced by Rodrigo for meeting the moral demands placed upon him as breadwinner were shared by several other Cuban 
men I engaged with during fieldwork. It was precisely in connection to this preoccupation of having to provide that Ernesto, for instance, felt he would not be up for the task, a scenario that informed his pessimist stance on his chances of entertaining any long-term relationship with a Cuban woman:

"It may be OK at the beginning you know, but then she may start to ask you for this and that, to buy such and such thing for the house, and so on and so forth. And I feel bad not being able to do it, not to be able to make her happy $[\ldots]$ If you go out with a Cuban woman, she expects you to buy at least a couple of beers, and how do I do that?"

What I sensed in this conversation we had was Ernesto's worry of disappointing a Cuban girlfriend on the economic side, and his ensuing reluctance in even trying to establish such a relationship. As he put it, he liked Cuban women more than foreign ones, but right now the latter were the ones that were up for him ("las que me tocan").

Ernesto's friend Aurelio, a white complexioned neighbor of his, still in his early twenties and rather unfamiliar with the world of jineterismo, had a more trenchant assessment of Cuban women: all of them were interesadas, interested in what you had, in your money. As a result, it was nowadays impossible to have a normal relationship with them. "Love doesn't exist anymore" ( $E l$ amor ya no existe), maintained Aurelio, and this was why he now felt attracted to foreign women. With foreign women, he argued, you could still have a normal love relation. He illustrated this with the story of a brief affair he had just had with a young Spanish girl, an experience he had really enjoyed: "She wanted nothing more than love, and to feel good together. [...] European women are good; they only want love and sentiment. Cuban women have much wickedness [maldad]," he added. As we discussed the issue further, Aurelio clarified that it was the fault of the system ("es el sistema"), in Cuba, that everything was now por interés. "Everyone is in need" [tiene necesidades], and needs "deform everything," confirmed Ernesto. In this context, Ernesto went on arguing:

"Love becomes a secondary preoccupation. When your belly is empty, love may as well work the first days, but if you [the man] keep bringing back home boiled yam [boniato hervido], love gets lost, and goes screw itself [se va a la mierda]... It's obvious that the woman wants first of all to have the things she needs, and this [the present context] has changed things.

Also, if a woman can chose between a rough man who beats her [un bruto que le da golpes, hinting at a typical Cuban man], and one [a foreigner] that takes her out for dinner, makes her happy, treats her well and cares for her, she will go with a foreigner... Imagine that the kitchen breaks down, and 
one [Cuban man] tells her to sort it out and repair it herself, while the other [foreigner] buys her a new one.

In this system, where people have needs [necesidades], it's normal, women are forced to look for these things in the first place. [They have to] think about the child they may want to have, and about who is going to help them."

While Ernesto and Aurelio articulated here a very widespread critique in contemporary Cuba about the generalization and increasing predominance of "relations for interest" (relaciones de interés, i.e. instrumentally motivated) - as opposed to normal, "real" relationships (Fosado 2005) and "true love" (Lundgren 2011) - they were also explaining this negative trend with the present situation of economic crisis, normalizing it via a contextualization in the current exceptional circumstances. ${ }^{8}$ Insofar the Cuban context was judged responsible for "deforming" how things should have "normally" been, we are confronted here with a discourse of exception, a "normative politics" (Povinelli 2006: 208) that did not tarnish the ideal of pure love, but simply displaced it elsewhere, in other places or other times. For Aurelio and Ernesto, such "regulatory ideal" (Povinelli 2006: 208) ought to inform people's practices under normal conditions, but since these conditions were now lacking in the Cuban milieu, the two of them were looking toward relationships with foreigners as a possible ground for its realization. Indeed, Ernesto and Aurelio aspired to something more than a life dominated by economic needs and responsibilities, and were hoping for emotional fulfillment in true love and intimacy, ideals that they valued highly. In contrast to the bleak prospects they projected on relationships with Cuban women, intimacy with foreign women appeared in this sense as the realm in which true love was still possible.

As Umberto once put it to me, rather provocatively: "Cuban women want sex, and you have to pay, tourist woman want sex, and love!" (iLas cubanas quieren sexo, y hay que pagar; las turistas quieren sexo, y amor!). This contrastive vision, not uncommon among my Cuban research informants, ended up constituting two relationally opposed and rather purified versions of intimacy: sex for money on the one hand, and sex and love on the other. But how did such trope of love find expression, once we consider that the economic could also intervene in relationships between Cuban men and tourist women, and how did it articulate with notions of masculinity?

8 Alcázar Campos (2009) Lundgren (2011), and Härkönen (2015, this issue) discuss this question further, showing how gendered normativities and couple relationships are being affected by economic instability and crisis in contemporary Cuba. 
“ROMANTIC LOVER"

When talking about his aspirations in regards to relationships with tourist women, Umberto repeatedly told me that love was what he hoped for, to find a nice woman he felt comfortable with and could set up a family together, possibly have some kids, no matter in which country, abroad. Umberto was regularly getting money and gifts from his European girlfriends, and when I asked him why he kept looking for new partners and wasn't content with the ones he had, he replied with an ironic, almost guilty smile - as if acknowledging his internal struggles and contradictions - that "money doesn't fall from the sky" (el dinero no cae del cielo). He was referring to the fact that his relationships had ups and downs, and didn't provide any stable emotional and economic rewards that could appease him and enable him to stay put and satisfied with what he had. Therefore, he kept doing what he did best, moving forward with his everyday struggle (lucha). Umberto had several Cuban girlfriends too, relations that he cultivated also thanks to the resources that he got from tourists. He explained that in his neighborhood, a marginal and relatively poor area of Havana, if you had 5 CUC (approximately 5 USD) you could "fuck the best young mangoes" (beautiful girls) that were around. But to move from a relation with these "fun girls" (chicas divertidas, girls to have a good time with) - as Aurelio once put it referring to a similar deal - to a relationship with a "serious girl" (chica seria), was not so easy. Drawing again on Wilson (1969), we may argue that what was at stake here was also one's ability to move from a value system based on reputation (a lot of sexual feats with many chicas divertidas) to one of respectability (a married family life with a chica seria). As Umberto told me, the good, serious relationship he once had with a Cuban woman had been damaged when her family started complaining and criticizing Umberto's lifestyle, and more particularly his promiscuous relationships with foreign women.

After more than a decade relating with tourist women, Umberto was now in search of a "serious person" (una persona seria), a foreigner who would take seriously the possibility of having a long term, love relationship with him. Opposed to the persona seria was the bandolera (litt. bandit): someone who was just looking for sex, fun, and short-term gratification in the exceptional frame of one's holiday without taking any longer-term commitment - as many tourists seemed more and more inclined to do nowadays, or so the criticism went. The bandolera critique was quite widespread among the men I frequented, who occasionally went as far as qualifying some tourist women as sexual exploiters. This reproach could converge with resentment towards the privileged economic position of the visitors. In relation to this last point, my informants tended to retort that whatever tourists might think of their economic power and what it could afford them, all their money could not buy them, nor direct their decisions and choices. 
Proudly telling a friend why he had broken his promising relationship with a Spanish woman, Manuel, who often boasted about his macho qualities, was lapidary in his remarks: "Because they have some money, they think they can do what they want: go to hell I tell them! You know I am rough [soy un bruto]." Similarly defiant were the remarks of Carlos, a Rasta in his early sixties who had been on and off in a relation with a very rich German woman for more than a decade, and had finally parted with her, apparently also due to conflicts over his spending too much time and money with his Cuban friends. As he unburdened all his frustration and boasted his intransigent manly attitude, he told Ernesto and me:

"This German woman, always trying to control me, to put herself above me. I told her, go to hell! Who gives a shit if you are a millionaire? Look I prefer to stay here on the street and sell maní [roasted peanuts], than to have to do what you tell me, to stay under your control. I have my friends and when I want to stay with them I do what I want!"

Here we see surfacing again the tension and the dilemmas occasioned by the asymmetric positionings of tourist women and Cuban men, as economic vectors of power clashed with gendered ones.

To have a woman openly paying for a man, particularly when this was done under public scrutiny, was widely considered as "ugly" (feo) and humiliating by my informants. In the realm of the street, of cafes and bars, and setting aside perhaps those tourism contexts where jinetismo was most normalized and accepted, this notion was to be kept at bay, as it threatened the men's self-esteem and situated sense of self. Sometimes, very practical arrangements could be found to avoid exposing such shameful dependency on the women. This appeared in the story that Rodrigo and Emilio - another white Cuban man in his mid-thirties - recounted me about the amazing journey they once took across the island with their tourist girlfriends, a holiday that was entirely sponsored by the two young Europeans in question. On that occasion, to avoid that the women could be seen paying for the men - be it for drinks, food, or transportation - Emilio and Rodrigo had asked their girlfriends to let them carry the cash. This way, they could be seen by others as the ones taking out the money from their wallets and settling bills. With this move, the two men were also "taking care" of the women, ensuring no one would cheat them on prices.

In this and other similar other stories I heard, the Cuban men would try to take the lead, relying on their legitimacy as insiders to guide their tourist girlfriends around, activating their power-knowledge of local customs and circumstances and encouraging the foreigners to do things the "Cuban way" (as opposed to the "tourist" one) so as to live the "real" Cuba and save money at 
the same time. In a way, this could be seen as a contribution that ultimately benefitted the tourist's wallet too. "Right from the start I tell them: 'Look, I am poor. How much did you intend to spend for your holiday here? Well, give this to me, let me be in charge, and you will see [how much you will save]'." This is how Yoanni, a young Rasta in his mid-twenties, put it, to highlight his material input to the relations he had with tourists. He abhorred seeing his partners waste money in the allegedly overcharged bad quality food and drinks served in tourism locations, and was not going to let this happen, having "his woman" cheated this way. Yoanni was also very adamant about the fact that, while poor and with very limited resources compared to the tourists, he was not a prostituto, and would never wait passively for women to do things for him. One had to show initiative, do his part. As much as possible, one had to strive to be the man that took care of his woman. At the same time, by openly manifesting their being in charge of their foreign partners, people like Yoanni were also clearly signalling to other potential Cuban male competitors that these women were off-limits and under their control (see Pruitt and LaFont 1995 for a Jamaican parallel).

Via the relational idioms of care (cuidado), affection (cariño), and love (amor), relationships between Cuban men and tourist women took on essential qualities that could also enable people to obviate to economic asymmetries and the tensions they generated, or at least to recast the uneven economic transactions taking place in a different light. Umberto's looking for a persona seria and for love relationships was echoed in the discourses of other research participants. Some of these men had enjoyed in their younger age a lot of on-off relationships with tourist women, accumulating a wealth of sexual experiences that had certainly accrued their reputation among peers, but were now looking for something else - and the reputation-respectability lens may once again be fruitfully deployed here. For my friend Emilio, the prospect of being in love with his tourist partner, of settling down with her and building a family together, was now all that mattered. In his early thirties, Emilio had been promised marriage by his German lover, and had travelled to Germany only to find himself "used for sex" during two months - as he put it - and with no wedding prospect in sight. "I am not a sex machine" was his outraged reaction, as he complained about the tourists' misrecognition of his ability to love and need for love. In the course of our long and repeated discussion about such issues, Emilio acknowledged that the peak of his success with tourist women had passed. He was getting "old and boring" (viejo y pesado), had lost his freshness and appeal, and in his gloomiest mood told me it was now almost impossible for him to find a partner at all, be it tourist or Cuban, apart perhaps some old foreign "granny" thirsty for sex and desperately looking for a younger man. His chances with Cuban women were presently very low, he maintained, not only due to his age and worsening looks, but mainly because he had no 
interesting job or income that would make him an appealing candidate for a long term relationship. That was the depressing scenario worrying Emilio.

His critique of the "sex machine" paradigm was simultaneously a plea for being recognized as more than that, as capable, and in need of, deeper sentiments too. The self that was taking shape in these narratives was more in tune with romantic ideals of love than with sexual prowess and promiscuity. The emphasis was on one's emotional interiority, and on worth that was to be measured according to the same moral standards people tended to ascribe to tourists. A self that was not defined by penury and economic necessity - the exceptional conditions of generalized necesidad Ernesto and Aurelio told me about - but by universal principles of what it meant to be a full-fledged human being, in need of sentiments and affects as any other. We may draw here on Elizabeth Povinelli, who argues that it is precisely in love that one may "locate the hegemonic home of liberal logics and aspirations" (2006: 17). According to this view, "the ability to 'love' in an 'enlightened' way becomes the basis (the 'foundational event') for constituting free and self-governing subjects and, thus, 'humanity'" (Povinelli 2004, quoted in Faier 2007: 153).

Rather than being viewed as naïve complaints, self-victimization discourses, or tactically instrumental moves to entice guilt, compassion, and help from the foreigner, I consider that these discourses on love, need for love, and lack of love should be taken seriously and appreciated in their aspirational qualities too (Moore 2011), as claims to belong to a wider world from which many of my Cuban informants felt excluded, and to a universal way of being a respectable person in such world. What many of them aspired to was indeed to be able to live under "normal conditions of existence"- as opposed to the context of exceptionalism, enduring crisis, scarcity, and isolation they associated with Cuba, and which they wished to overcome. ${ }^{9}$

What is also important to consider here is what these claims and professions of love could afford, enable and achieve at a more pragmatic level too. Itself an "ethical demand" (Zigon 2013), love called for a certain commitment and continuity in the relationship, bringing to the fore a range of moral responsibilities and obligations. The ideal at play was that lovers surrender to one another with no calculation whatsoever, and help each other when required. For the Cuban men at stake, this could mean being sent a monthly

9 A fruitful parallel may be drawn here with Patico's (2009) reflections on how international matchmaking provides Russian women and American men a way to seek "normalcy" in their personal lives. To illuminate the Cuban case, equally pertinent lines of interpretation can be found in recent anthropological research on love and intimacy (see Cole and Thomas 2009; Constable 2009; Padilla et al. 2007; Povinelli 2006; Venkatesan et al. 201 1; Zelizer 2005), and more particularly in the approach adopted by Faier (2007) in considering the professions of love of Filipina migrants in rural Japan, as this author productively draws together the emotional, moral, and pragmatic affordances of such transnational relationships across difference and inequality. 
allowance to face the hardships of life in Cuba, or being able to marry their tourist partner and join them abroad to set up a family together. What was extremely important in preserving this moral configuration of love was for these responsibilities and obligations to be experienced not as love's defining motive, but rather as a sentiment-driven outcome of it. In other words, people first loved each other, and subsequently, simply naturally, helped each other out as much as they could. While we may object that this was a rather abstract and purified idealization of romantic love, it was the one to which many of the Cuban men I engaged with seemed to aspire, or at least to claim as something they were willing and able to achieve.

The form of "subjectification" and "self-stylization" (Moore 2011) emerging from such idiom of love was strikingly at odds with the one that Cubans tended to deploy when boasting about their sexual conquests with their peers. It was not grounded on the sexual potency and prowess, nor on the breadwinner ideal of masculinity. Rather, love here seemed to bring into play the notion of equally sentient human beings, and a less polarized gendered power configuration.

\section{CONCLUSION}

Throughout this article, I have adopted an approach to masculinities that calls for a situated and multidimensional understanding of Cuban men's affective, moral, and pragmatic concerns, as they moved in and out of the world of tourism in their everyday lives. From interactions taking place between peers to tourist-Cuban ones, from globally circulating discourses that reiterate colonial sexual stereotypes to street-corner gossiping and confidential self-reflection, I have highlighted the criss-crossing traffic of different models and vectors of masculinity, their contrastive deployments in a variety of contexts and scalar levels. Such deployments could alternatively generate unity and fracture, consistency and contradiction, harmonization and friction within the lives of Cuban men, who found themselves having to respond to different needs and aspirations, and were enmeshed in different lines of belonging. Part of the successes or failures of these men seemed to depend on their skills and proficiency in enacting a variety of masculinities, integrating and feeling comfortable with them all as equally functioning - albeit potentially contradictory - "embodied moral dispositions" (Zigon 2010).

It is possible to tease out some of the key (dis)continuities between the different situational enactments of masculinity I have examined. Images of sexual potency could easily traverse all situations, but could become an uncomfortable burden hampering the enactment of the romantic lover (as exemplified by Emilio's critique of the "sex machine" view; see also Simoni 2013). Such romantic lover, on the other hand, had to be kept in check when discussing with 
Cuban peers, so as not to appear too foolish and naïve in front of them. The breadwinner ideal could be played out with Cuban girlfriends, but its' relevance tended to be silenced when interacting with female tourists, only to come up as a reactive element when the tourist's economic-driven power made people feel uncomfortable and retort with pride that "no money can buy me!" Besides the task of mapping these various articulations, and retrace the possible configurations and (in)commensurabilities between different models and vectors of masculinity, what can be retained here at a more general level is the idea of dynamic, situated, tentative, and often paradoxical enactments of masculinity.

In the last section, I have emphasized the importance of recognizing Cuban men's aspiration to love, and of paying attention to the emotional, moral, and pragmatic possibilities this opened up both for them and for their tourist partners. Touristic encounters thus seemed to provide new venues for subjectification and self-stylization, leading people to attune masculinities to globally circulating ideals of romance and the loving partner. This, however, should not silence the fact that the very same Cuban people, in other contexts of interaction where other models of masculinity and moral imperatives prevailed - like when gossiping with peers - could dispassionately brag about their rough macho attitude and exclusively sexual feats with tourists. Instead of trying to resolve such contradictions, one of my aims here has been to engage in an "ethnography of moral reasoning" to provide "specific accounts of how people negotiate paradoxes in their daily lives" (Sykes 2009: 15; see Simoni 2013). Responding to competing demands and aspirations, Cuban men's purposeful alignments as "breadwinners," "sex machines," and "romantic lovers" afforded different relational possibilities and expressions of masculinity. It is by closely scrutinizing these possibilities that we can illuminate the transformations of masculinities that tourism engenders, and thus assess its potential to amplify and subvert (stereo)-typical configurations of "being a man" in present-day Cuba.

Through their experiences of intimacy with tourist women, Cuban men worked over their masculinities while also reassessing their relationships and ways of being with Cuban women. In this sense, tourism acted as a laboratory to rework one's sense of self and modes of relating to others inside and outside of the tourism realm itself. We are dealing here with a context - that of life in the tourism margins of a crisis-ridden Cuba - in which changing living conditions shed doubts on and came to question normative ideals of masculinity, calling for other "tactical alternatives" (Connell and Messerschmidt 2005: 847 ) to emerge. The men I worked with seemed often at pains to compose with the contrasting affective, moral, and pragmatic demands they were called to respond to "as men" in the different milieus in which they evolved, and strived to maintain a sense of worthiness in this intricate terrain. As Vale de Almeida puts it, "[t]he experience of men and women is a difficult dialogue between the polymorphous complexity of their feelings and the simplicity of 
social patterns" (1997: 142). Confronted with such simplicity, with limited frames of legibility and justification, the protagonists in this article strived to situationally align their selves to the models of masculinity they found available, while at the same time re-actualizing and re-working them.

\section{REFERENCES}

ABOIM, Sofia, 2012, "Sexualized bodies: masculinity, power and identity in Mozambique", Norma: Nordic Journal for Masculinity Studies, 7 (1): 67-90.

ALCÁZAR CAMPOS, Ana, 2009, "Turismo sexual, jineterismo, turismo de romance: fronteras difusas en la interacción con el otro en Cuba”, Gazeta de Antropología, 25 (1), available at < http://hdl.handle.net/10481/6856> (last access May 2015).

ALLEN, Jafari Sinclaire, 2007, "Means of desire's production: male sex labor in Cuba", Identities: Global Studies in Culture and Power, 14 (1-2): 183-202.

ALMEIDA, Miguel Vale de, 1997, "Gender, masculinity and power in Southern Portugal", Social Anthropology, 5 (2): 141-158.

ARGYRIADIS, Kali, 2005, "El desarrollo del turismo religioso en La Habana y la acusación de mercantilismo", Desacatos, 18: 29-52.

BERG, Mette Louise, 2004, "Tourism and the revolutionary New Man: the Specter of jineterismo in late 'Special Period' Cuba”, Focaal: European Journal of Anthropology, 43: 46-56.

CABEZAS, Amalia L., 2004, "Between love and money: sex, tourism, and citizenship in Cuba and the Dominican Republic", Signs, 29 (4): 984-1015.

CABEZAS, Amalia L., 2009, Economies of Desire: Sex and Tourism in Cuba and the Dominican Republic. Philadelphia, Temple University Press.

COLE, Jennifer, and Lynn M. THOMAS (eds.), 2009, Love in Africa. Chicago and London, The University of Chicago Press.

CONNELL, Raewyn, and James W. MESSERSCHMIDT, 2005, "Hegemonic masculinity: rethinking the concept”, Gender and Society, 19 (6): 829-859.

CONSTABLE, Nicole, 2009, "The commodification of intimacy: marriage, sex, and reproductive labor", Annual Review of Anthropology, 38: 49-64.

CORNWALL, Andrea, and Nancy LINDISFARNE, 1994, "Introduction", in Andrea Cornwall and Nancy Lindisfarne (eds.), Dislocating Masculinity: Comparative Ethnographies. London, Routledge, 11-47.

COUCEIRO RODRÍGUEZ, Avelino Victor, 2006, "Los pingueros y sus clientes", Proceedings of the VIII Conferencia Internacional de Antropologia, La Habana, Cuba, CD-ROM.

DAHLES, Heidi, 1997, "The new gigolo: globalization, tourism and changing gender identities". Focaal: European Journal of Anthropology, 30-31: 121-137.

DE ALBUQUERQUE, Klaus, 1998, "In search of the big bamboo", Transitions, 77: 48-57.

FAIER, Lieba, 2007. "Filipina migrants in rural Japan and their professions of love", American Ethnologist, 34 (1): 148-162. 
FERNANDEZ, Nadine, 1999, "Back to the future? Women, race, and tourism in Cuba", in Kemala Kempadoo (ed.), Sun, Sex, and Gold: Tourism and Sex Work in the Caribbean. Lanham, Rowman \& Littlefield Publishers, 81-89.

FERNANDEZ, Nadine, 2010, Revolutionizing Romance: Interracial Couples in Contemporary Cuba. New Brunswick, NJ, and London, Rutgers University Press.

FOSADO, Gisela, 2005, "Gay sex tourism, ambiguity and transnational love in Havana", in Damian J. Fernández (ed.), Cuba Transnational. Gainesville, University Press of Florida, 61-78.

FREEMAN, Carla, 2007, "Neoliberalism and the marriage of reputation and respectability: entrepreneurship and the Barbadian middle class", in Mark Padilla et al. (eds.), Love and Globalization: Transformations of Intimacy in the Contemporary World. Nashville, TN, Vanderbilt University Press, 3-37.

FROHLICK, Susan, 2007, "Fluid exchanges: the negotiation of intimacy between tourist women and local men in a transnational town in Caribbean Costa Rica", City and Society, 19 (1): 139-168.

FUSCO, Coco, 1997, “Jineteras en Cuba”, Encuentro de la Cultura Cubana, 4-5: 52-64.

GONZÁLEZ PAGÉS, Julio C., 2004, "Feminismo y masculinidad: ¿Mujeres contra hombres?", Temas, 37-38: 4-14.

GUTMANN, Matthew C., 1997, "Trafficking in men: The anthropology of masculinity”, Annual Review of Anthropology, 26: 385-409.

HANSING, Katrin, 2006, Rasta, Race and Revolution: The Emergence and Development of the Rastafari Movement in Socialist Cuba. Berlin, LIT Verlag.

HÄRKÖNEN, Heidi, 2015, "Negotiating desirability and material resources: changing expectations on men in post-Soviet Havana", Etnográfica, 19 (2): pp. 367-388.

HEROLD, Edward, Rafael GARCIA, and Tony DeMOYA, 2001, "Female tourists and beach boys: romance or sex tourism?”, Annals of Tourism Research, 28 (4): 978-997.

HODGE, Derrick G. 2001, "Colonization of the Cuban body: the growth of male sex work in Havana", NACLA Report on the Americas, 34 (5): 20-44.

JEFFREYS, Sheila, 2003, “Sex tourism: do women do it too?”, Leisure Studies, 22 (3): 223-238.

KEMPADOO, Kemala, 2004, Sexing the Caribbean: Gender, Race, and Sexual Labor. New York and London, Routledge.

KNEESE, Tamara, 2005, "La mulata: Cuba's national symbol”, Cuba in Transition, 15: 444452.

KUMMELS, Ingrid, 2005, "Love in the time of Diaspora: global markets and local meaning in prostitution, marriage and womanhood in Cuba", Iberoamericana, 5 (20): 7-26.

LUNDGREN, Silje, 201 1, Heterosexual Havana: Ideals and Hierarchies of Gender and Sexuality in Contemporary Cuba. Uppsala, Uppsala University, PhD thesis.

MOORE, Henrietta L., 2011 , Still Life: Hopes, Desires and Satisfactions. Cambridge, Polity Press.

MOREL, Géraldine, 2012, Etre abakuá à La Havane: pouvoir en jeu, enjeux de pouvoir et mise en scène de soi. Neuchâtel, University of Neuchâtel, PhD thesis.

OXLUND, Bjarke, 2012, “It made me feel good and man enough': love, sex and situational masculinity in a South African university context", Norma: Nordic Journal for Masculinity Studies, 7 (1): 25-49.

PADILLA, Mark, et al. (eds.), 2007, Love and Globalization: Transformations of Intimacy in the Contemporary World. Nashville, TN, Vanderbilt University Press. 
PALMIÉ, Stephan, 2004, "Fascinans or tremendum? Permutations of the State, the body, and the divine in late-twentieth-century Havana", New West Indian Guide, 78 (3-4): 229-268.

PATICO, Jennifer, 2009, "For love, money, or normalcy: meanings of strategy and sentiment in the Russian-American matchmaking industry”, Ethnos, 74 (3): 307-330.

PISCITELLI, Adriana, 2014, "Transnational sex travels: negotiating identities in a Brazilian 'tropical paradise' ”, in Sonia E. Alvarez et al. (eds.), Translocalities/Translocalidades: Feminist Politics of Translation in Latin/a Américas. Durham and London, Duke University Press, 277-297.

POVINELLI, Elizabeth A., 2006, The Empire of Love: Toward a Theory of Intimacy, Genealogy, and Carnality. Durham and London, Duke University Press.

PRUITT, Deborah, and Susanne LaFONT, 1995, "Love and money: romance tourism in Jamaica", Annals of Tourism Research, 22: 422-440.

SANCHEZ TAYLOR, Jacqueline, 2000, “Tourism and 'embodied' commodities: sex tourism in the Caribbean”, in Stephen Clift and Simon Carter (eds.), Tourism and Sex: Culture, Commerce and Coercion. London and New York, Pinter, 41-53.

SIERrA MADERO, Abel, 2006, Del Otro Lado del Espejo: La Sexualidad en la Construcción de la Nación Cubana. La Habana, Casa de las Américas.

SIMONI, Valerio, 2008, "Shifting powers: the (de)stabilization of asymmetries in the realm of tourism in Cuba”, Tsansta: Review of the Swiss Anthropological Society, 13: 89-97.

SIMONI, Valerio, 2011 , "Linterculturalité comme justification: sexe 'couleur locale' dans la Cuba touristique", in Anne Lavanchy, Fred Dervin and Anahy Gajardo (eds.), Anthropologies de l'interculturalité. Paris, L'Harmattan, 197-225.

SIMONI, Valerio, 2013, "Intimate stereotypes: the vicissitudes of being caliente in touristic Cuba", Civilisations: Revue internationale d'anthropologie et de sciences humaines, 62 (1-2): 181-197.

SIMONI, Valerio, 2014, "Coping with ambiguous relationships: sex, tourism, and transformation in Cuba", Journal of Tourism and Cultural Change, 12 (2): 166-183.

STOUT, Noelle, 2007, "Feminists, queers and critics: debating the Cuban sex trade", Journal of Latin American Studies, 40: 721-742.

SYKES, Karen, 2009, "Residence: moral reasoning in a common place: paradoxes of a global age”, in Karen Sykes (ed.), Ethnographies of Moral Reasoning: Living Paradoxes of a Global Age. New York, Palgrave Macmillan, 3-40.

VENKATESAN, Soumhya, et al., 2011 , “The anthropological fixation with reciprocity leaves no room for love: 2009 meeting of the Group for Debates in Anthropological Theory", Critique of Anthropology, 31 (3): 210-250.

VIGOYA, Mara Viveros, 2001, "Contemporary Latin American perspectives on masculinity”, Men and Masculinities, 3 (3): 237-260.

WILSON, Peter J., 1969, "Reputation and respectability: a suggestion for Caribbean ethnology", Man, 4 (1): 70-84.

ZELIZER, Viviana A., 2005, The Purchase of Intimacy. Princeton, NJ, Princeton University Press.

ZIGON, Jarrett, 2008, Morality: An Anthropological Perspective. Oxford and New York, Berg. ZIGON, Jarrett, 2010, "Moral and ethical assemblages: a response to Fassin and Stoczkowski”, Anthropological Theory, 10 (1-2): 3-15.

ZIGON, Jarrett, 2013, "On love: remaking moral subjectivity in postrehabilitation Russia”, American Ethnologist, 40 (1): 201-215. 